\title{
Patent row splits fish identity researchers
}

Paris. A bitter conflict has arisen over a patent on a technique for tracing the genetic origin of canned tuna fish, stirred by overlapping disputes over the validity of the patent itself, and its implications for the relationship between rival research teams.

The conflict is pitting taxonomists and other researchers, backed by the United Kingdom Ministry of Agriculture, Fisheries and Food (MAFF), against the holder of the patent, the Canadian company Bio-ID, and its European licensee, Atlangène of France.

The patent, which describes a technique for identifying the tuna species from which a sample has been taken, has been granted in both the United States and Europe. The socalled FINS (Forensically Informative Nucleotide Sequencing) technique involves isolating DNA from the sample, amplifying it with the polymerase chain reaction, and comparing its nucleotide sequences with those of known species in a database.

The patent was granted to William Davidson and Sylvia Bartlett of Memorial University in Newfoundland. Bartlett and Davidson - the latter associate dean of science at the university - later transferred their rights to Bio-ID, a company set up jointly with the university, and of which they are respectively president and vice-president for research and development.

The two scientists originally developed the technique for Canada's Department of Fisheries and Oceans. The department wanted to identify carcasses of blue-fin tuna in order to prevent poaching of the regulated species, which can fetch Can $\$ 1,000$ 20,000 in Japan's sashimi market. Davidson claims that the development of FINS has already stopped such poaching.

Last month, however, Susan Pryde, a researcher at MAFF's Torrey Marine Research Station near Aberdeen in Scotland, launched an appeal to researchers via the Internet for papers demonstrating that the patented technique was not novel. Pryde says Atlangène has told her that her own work on the identification of tuna species infringes the Bio-ID patent.

MAFF says it does not believe the Torrey group's research infringes the patent, as it is "not using the test commercially" - under European patent law scientists are allowed to use a patented process for research purposes without needing either a licence or the permission of the patent holder.

But the outcome of similar patent conflicts in the past suggests that Atlangène may have a case. The MAFF group's research appears to be aimed at developing the technique patented by the Canadians, and the dispensation given to research under European patent law does not apply to research carried out to satisfy a regulatory body.

Indeed, Pryde admits that MAFF may be interested in eventually using the technique

for enforcing regulations, in which case it could seek a "crown licence": a compulsory licence of a patented technique which can be obtained when a government wants to use it to enforce legislation.

Although Pryde argues that "we wouldn't want to commercially exploit a test as such, but only use it to protect consumers", jurisprudence again suggests that research aimed at applying for compulsory licences counts as commercial use under European patent law (see Nature 376, 622; 1995).

Both Davidson and Atlangène argue that the Torrey group's position seems self-contradictory. "If they aren't wanting to commercialize the work, why do they want to challenge the patent?" asks Davidson.

Much of the tension between the warring parties seems to stem from a long-running dispute between the Torrey Laboratory and the patent holders. In a letter sent to the European Commission in October 1994, Davidson and Bartlett challenged a grant application by the Torrey laboratory on the grounds that the project would duplicate the efforts that have already been made to develop techniques that are now in commercial use in Europe and North America.

"You can imagine our surprise when we learned that the European Community was awarding a substantial grant to a consortium from the UK, Germany and Spain" to develop exactly the same process, says Davidson, who suggested last year that, if the commis-

\section{IMAGE UNAVAILABLE FOR COPYRIGHT REASONS}

Murky waters: a blue-fin tuna, at the centre of dispute over the patent on a genetic identification technique.

sion wanted to award such a grant, it would be "more appropriate" to award it to Atlangène.

Pryde claims that her attempts to stimulate a challenge to the patent are based on the grounds that the technique it describes are "not novel". She also predicts that, having negotiated rights to the Bio-ID patent, Atlangène "is not going to leave us, or others using similar techniques, alone."

But the Torrey group is also aware that a successful challenge to the patent would put an end to any infringement claims by Atlangène. MAFF officials say that they are "keen to see the patent challenged", given, it claims, that it was based on research "that was already in the public domain." Indeed, MAFF itself is believed to be preparing a formal challenge to the patent.

Davidson describes Pryde's Internet appeal as disingenuous, arguing that while Bio-ID may contest applied research such as that carried out at Torrey, it has no intention of blocking fundamental academic research. "We don't, nor shouldn't, expect royalties or other fees if the process is used strictly for academic research", he says. "We're completely happy about that sort of use."

Atlangène says similarly that the patented identification technique can be freely used by any laboratory wishing to use it for noncommercial purposes such as fundamental research in phylogenetics.

But Pryde's Internet appeal has struck a nerve among taxonomists and researchers in molecular evolution worldwide, who fear the patent could still impede their research. One scientist who attended a workshop on molecular evolution held at Wood's Hole in Massachussetts last month said that participants were "astonished" that such a patent had been granted.

One reason is that many researchers feel that the patent should not have been granted because of the extent to which FINS is based on techniques which were widely used when Bartlett and Davidson filed their application in 1990.

They disagree with the conclusion of the European Patent Office that research papers describing similar techniques, which were published before the patent applica-

s tion, did not constitute "prior art", 总 and have been trawling the literature for other papers that could be 喜 used in any challenge.

Sir Alec Jeffreys, for example, the $\frac{\text { W }}{2}$ British researcher who pioneered (and successfully patented) some of the original techniques for DNA 'fingerprinting', said this week he did not see any novel products in the work that would be appropriate for patenting. "I would be extremely alarmed if any patent agent granted this patent," says Jeffreys.

Bio-ID and Atlangène are both refusing to comment on statements by Pryde and others statements about the validity of the patent in the absence of a formal challenge. Davidson admits the patented procedure is based on established techniques. But he points out that the patent offices on both sides of the Atlantic have accepted their claim that "the combination of such techniques made [the patent] inventive".

Some researchers are also concerned about the breadth of the Canadian patent, which covers not just tuna fish but all "eukaryotes and prokaryotes". Davidson maintains that Bio-ID would press for infringement not just for cases involving tuna fish, but also for cases covering tigers to bacteria.

Declan Butler 